\title{
Integrated safety system for workers and traffic in railway transport
}

\author{
Anna Basalaeva ${ }^{1, *}$, Vladimir Medvedev ${ }^{1}$ and Pavel Strykov ${ }^{1}$ \\ ${ }^{1}$ Siberian Transport University, Dusi Kovalchuk st., 191, 630049, Novosibirsk, Russia
}

\begin{abstract}
The safety and stability of the transportation process in railway transport is provided by a set of various measures. However, violations, incidents and accidents continue to occur, causing significant damage to workers, infrastructure, natural environment, and population. The relevance of the study is determined by the need of finding ways to prevent this damage and reduce the socio-economic and environmental costs. The purpose of the study is the development of an integrated safety system for traffic and workers in railway transport. A set of theoretical and experimental research methods has been applied: physical, simulation and computer modeling; statistics, theory of probability and others. The main result of the development is a complex system of interrelated units: "Sphere of activity"; "Qualification of personnel"; "The required level of work"; "Rating of danger"; "Optimization and technical and economic assessment of company costs". Requirements for an information management system were developed for the holding company "Russian Railways". This system allows personal accounting of the qualifications of employees (over 900 thousand) in the main areas of activity: ensuring traffic safety; occupational safety and health; transport, industrial, fire and electrical safety; protection in emergency situations. The project of the normative and technical document regulating the corresponding changes is substantiated. On the basis of theoretically processed experimental material, the expected development efficiency was established: $8-10 \%$.
\end{abstract}

\section{Introduction}

Modern railway transport is a complex natural and technical complex (NTC) or a natural and technogenic system (NTS). To ensure the safe and stable transportation process in railway freight and passenger transport, a large range of technical, technological, economic, logistical, environmental, and other tasks is being solved. However, violations of the transportation process, incidents and transport emergency situations continue to occur, causing significant damage to workers, transport infrastructure, natural environment and population of the surrounding areas. Annual losses are: economic - 1-5 billion rubles [1]; material - damage to the infrastructure of thousands of cars, dozens of locomotives and other technical means [2]; ecological - millions of rubles [3]; loss of life and health of employees - 28 people fatally injured and about 200 people with a noticeable deteriorating health status [4]. All this makes us speak not so much of the systematic improvement of the

\footnotetext{
*Corresponding author: nushaa1@mail.ru
} 
existing situation, but of the formation of new approaches to the safety system for workers and traffic in railway transport. After 180 years of successful construction and operation of railways in the Russian Empire, the USSR and the Russian Federation, the question of forcing efforts to design and build speed and high-speed railway lines in our country was raised on the agenda for the development of the country. Separate comparative parameters are presented in Table 1. Along with the technical, economic, social, and environmental components, an important role is played by considerations of geopolitics, state strategy and international prestige of Russia. The relevance of the study is determined by the need of finding ways to prevent damage from loss of health and life of workers; incidents, crashes and traffic accidents, and also a general decrease in the economic, social and environmental costs of the transport process.

\section{Methods of research}

The purpose of the study was to develop the baseline provisions for an integrated system of workers' safety and traffic safety in railway transport. The basis for obtaining the results was theoretical and experimental methods of research of transport operations, such as physical, simulation and computer modeling; statistics and theory of probability; and others. In this paper, an attempt has been made to explain an integrated safety system for workers and traffic in railway transport, with an accent on the personnel component, the provision of skilled workers. The initial methodological premises, among other things, are:

- investments in preventive safety measures of complex systems are economically viable, economically repaid, prevented damage exceeds expenses by 5-10 times $[1,5]$.

- investments in the training and professional development of employees are economically most effective; the effectiveness of other components of the safety system (technology, production environment) is several times lower [6, 7].

\section{Results of the research}

In study [6], we showed that under the conditions of a relative decrease in incomes and underinvestment of the Open Joint Stock Company "Russian Railways" (JSC "RZD"), it is forced to choose low-cost, but most effective methods. But the Company does not have a sufficient understanding of the role of integrated safety and the fact that the most effective methods, as the world experience shows, are primarily related to motivation and human factor.

Table 1. Comparative parameters of conventional, speed and high-speed railway lines.

\begin{tabular}{|c|c|c|c|c|}
\hline No & Parameter & $\begin{array}{l}\text { Conventional * } \\
\text { railways }\end{array}$ & Speed lines & High-speed lines (HSL) \\
\hline 1 & $\begin{array}{l}\text { Average speed, } \\
\mathrm{km} / \mathrm{h}\end{array}$ & 50 & 170 & 300 \\
\hline 2 & $\begin{array}{l}\text { Maximum } \\
\text { speed, } \mathrm{km} / \mathrm{h}\end{array}$ & up to 140 & up to 220 & up to 600 \\
\hline 3 & $\begin{array}{l}\text { Time period } \\
\text { (beginning) }\end{array}$ & 1837 & 1950 & 2009 \\
\hline 4 & $\begin{array}{l}\text { Human factor: } \\
\text { - human } \\
\text { resources; } \\
\text { - requirements } \\
\text { for personnel; }\end{array}$ & $\begin{array}{l}\text { - redundancy of the } \\
\text { personnel of narrow } \\
\text { specialization; } \\
\text { - one qualification } \\
\text { is enough }\end{array}$ & $\begin{array}{l}\text { - reduction of the } \\
\text { number } \\
\text { personnel with a } \\
\text { narrow } \\
\text { specialization; } \\
\text { - professional } \\
\text { development } \\
\text { (optionally) for the } \\
\text { expansion of }\end{array}$ & $\begin{array}{l}\text { - a noticeable creation of new jobs; } \\
\text { - almost continuous compulsory } \\
\text { professional development of } \\
\text { specialists }\end{array}$ \\
\hline
\end{tabular}




\begin{tabular}{|c|c|c|c|c|}
\hline & & & $\begin{array}{l}\text { professional } \\
\text { opportunities }\end{array}$ & \\
\hline 5 & $\begin{array}{l}\text { Socio-economic } \\
\text { factor }\end{array}$ & $\begin{array}{l}\text { - development of } \\
\text { service between } \\
\text { major cities; } \\
\text { - international } \\
\text { transportation; } \\
\text { - strengthening of } \\
\text { economic } \\
\text { international } \\
\text { relations; } \\
\text { - increase of } \\
\text { economic potential } \\
\text { of the country. }\end{array}$ & $\begin{array}{l}\text { - reduction of the } \\
\text { delivery time for } \\
\text { passengers and } \\
\text { cargo; } \\
\text { - increasing the } \\
\text { mobility of } \\
\text { economically active } \\
\text { population; } \\
\text { - creation of } \\
\text { intercontinental } \\
\text { transport corridors }\end{array}$ & $\begin{array}{l}\text { - export of progressive foreign } \\
\text { technologies and import of } \\
\text { domestic ones; } \\
\text { - providing the population with } \\
\text { high-speed railway passenger } \\
\text { transportation services comparable } \\
\text { to aviation by the delivery time; } \\
\text { - formation and development of a } \\
\text { unified system of intermodal } \\
\text { complexes "airports - HSL - urban } \\
\text { transport"; } \\
\text { - increase of prestige of the country }\end{array}$ \\
\hline 6 & $\begin{array}{l}\text { Ecological } \\
\text { factor }\end{array}$ & $\begin{array}{l}\text { - systematic } \\
\text { reduction of } \\
\text { emissions of } \\
\text { harmful substances } \\
\text { into the } \\
\text { atmosphere, sewage } \\
\text { treatment, noise } \\
\text { reduction and } \\
\text { improvement of the } \\
\text { acoustic climate, } \\
\text { processing of waste } \\
\text { products of railway } \\
\text { transport facilities }\end{array}$ & $\begin{array}{l}\text { - the widespread } \\
\text { use of the best } \\
\text { available } \\
\text { technologies that } \\
\text { reduce the impact } \\
\text { on nature }\end{array}$ & $\begin{array}{l}\text { - reduction of noise due to the use } \\
\text { of high-speed trains in passenger } \\
\text { traffic; } \\
\text { - reduction of emissions into the } \\
\text { atmosphere due to the use of } \\
\text { alternative sources of fuel (for } \\
\text { example, natural gas); } \\
\text { - practically "environmentally } \\
\text { friendly" transport; } \\
\text { - improvement of the image in the } \\
\text { world transport space }\end{array}$ \\
\hline
\end{tabular}

First of all, it is necessary to structure the notion of "safety" in railway transport, which is connected with such spheres of industrial activity of transport as: occupational health and safety, industrial safety, safety of work at heights, electrical safety, fire safety, traffic safety in railway transport, protection in emergency situations, transport safety, road safety, first aid, environmental safety, waste management. The components of the integrated safety system for workers and traffic in railway transport, as well as the frequency (minimum) with which employees of the company must be trained (advanced training, retraining) are presented in Table 2 .

Table 2. Components of an integrated safety system for workers and traffic in railway transport.

\begin{tabular}{|l|l|l|l|}
\hline No & Types of safety & \multicolumn{2}{l|}{ Periodicity of training * } \\
\cline { 3 - 4 } & & $\begin{array}{l}\text { Leaders, } \\
\text { specialists }\end{array}$ & $\begin{array}{l}\text { Workers, } \\
\text { employees }\end{array}$ \\
\hline 1 & Occupational health and safety & $\begin{array}{l}1 \text { time in } 3 * \text { and } \\
5^{* *} \text { years }\end{array}$ & annually \\
\hline 2 & Industrial safety & 1 time in 5 years & 1 time in 3 years \\
\hline 3 & Safety of work at heights & 1 time in 5 years & 1 time in 3 years \\
\hline 4 & Electrical safety & 1 time in 3 years & annually \\
\hline 5 & Fire safety & 1 time in 3 years & annually \\
\hline 6 & Traffic safety in railway transport & 1 time in 5 years & 1 time in 5 years \\
\hline 7 & Protection in emergency situations & 1 time in 5 years & annually \\
\hline 8 & Transport safety & 1 time in 5 years & 1 time in 5 years \\
\hline 9 & Road safety & 1 time in 5 years & 1 time in 5 years \\
\hline 10 & First aid & annually & annually \\
\hline 11 & Environmental safety & 1 time in 5 years & - \\
\hline 12 & Waste management & 1 time in 3 years & - \\
\hline
\end{tabular}

The organization of training, advanced training, retraining is a necessary, compulsory, but also quite difficult in modern conditions and very expensive activity for JSC "RZD". Each branch of JSC "RZD", as well as its subsidiary and affiliate company (SAC), must 
carry out the unified technical policy of the company. Data on such important branches of JSC "RZD" as railways are presented in Table 3. The total number of railway workers was almost 800 thousand, and the entire Holding - about 900 thousand.

We propose approaches how to optimize these processes and manage them, taking into account the changing social and economic conditions in our country, including as well accounting of the inevitable upcoming expansion of the share of servicing of speed and high-speed lines (sections, directions, operating domains).

Taking into account the multifactority, complexity and significant degree of uncertainty of the task of managing complex safety in the current period and for the future, we developed the concept of the information management system of the holding JSC "RZD" with the working title "Technospheric Safety" (IMS "TS"), and also the elements of requirements to it.

The basis of the system should be a control program that operates several interrelated units, such as:

- ensuring safety, traffic stability, reducing the frequency of incidents, dangerous and emergency situations, structuring costs by types of tasks;

- sphere of industrial activity;

- required level of qualification of work;

- required qualification of the personnel;

- danger level of work;

- safety rating of the employee;

- optimization and technical and economic assessment of the company's costs.

\section{Results}

As it was said above, the subjects of economic activity should bear the costs of ensuring safety, but a reasonable tactic and strategy provides the prevented damage that exceeds costs by 5-10 times. Table 4 shows the structure of tasks to reduce the impact of negative factors affecting the frequency of incidents, dangerous and emergency situations

Another target indicator of both the transport safety system and the IMS "TS" is a phased solution of the strategic task to increase safety and reduce risks, which is reflected in the reduction of industrial injuries for conventional traffic by 15 to 30 times. For highspeed traffic, taking into account the additional multiplying factor $(\mathrm{K})$ with respect to the standard value $\left(\mathrm{K}_{0}\right)$ based on the Weber-Fechner law and the L. Bertalanffy principle $\mathrm{K} / \mathrm{K}_{0}$ $=\ln 600 / 140=1.45$, i.e. for a worker servicing traffic, the risk is increased by $45 \%$ with all other things being equal.

Table 3. Main indicators of branches of JSC "Russian Railways" for 2017.

\begin{tabular}{|l|l|l|l|l|}
\hline Railway & $\begin{array}{l}\text { Operating } \\
\text { length, } \\
\mathrm{km}\end{array}$ & $\begin{array}{l}\text { Number of } \\
\text { employees, } \\
\text { people }\end{array}$ & $\begin{array}{l}\text { Number of goods } \\
\text { transported, } \\
\text { million tons }\end{array}$ & $\begin{array}{l}\text { Number of passengers } \\
\text { transported, million } \\
\text { passengers }\end{array}$ \\
\hline East Siberian & 3877 & 39603 & 196,4 & $\begin{array}{l}4,2 \text { (long-distance) } \\
10,3 \text { (suburban) }\end{array}$ \\
\hline Gorkovskaya & 5331 & 43318 & 248,2 & $\begin{array}{l}16,8 \text { (long-distance) } \\
33,8 \text { (suburban) }\end{array}$ \\
\hline Far Eastern & 6871 & 51484 & 178,9 & $\begin{array}{l}4,1 \text { (long-distance) } \\
6,2 \text { (suburban) }\end{array}$ \\
\hline Transbaikalian & 3321 & 43976 & 148,6 & $\begin{array}{l}2,7 \text { (long-distance) } \\
0,9 \text { (suburban) }\end{array}$ \\
\hline West Siberian & 4182 & 56762 & 406 & $\begin{array}{l}8,2 \text { (long-distance) } \\
38,1 \text { (suburban) }\end{array}$ \\
\hline
\end{tabular}




\begin{tabular}{|l|l|l|l|l|}
\hline Kaliningrad & 668 & 3742 & 13,4 & $\begin{array}{l}482 \text { Tbc. (long-distance) } \\
3,1 \text { (suburban) }\end{array}$ \\
\hline Krasnoyarsk & 3158 & 27957 & 78,8 & $\begin{array}{l}1,7 \text { (long-distance) } \\
6,2 \text { (suburban) }\end{array}$ \\
\hline Kuybyshevskaya & 4728 & 42639 & 205,7 & $\begin{array}{l}12,4 \text { (long-distance) } \\
14,1 \text { (suburban) }\end{array}$ \\
\hline Moscow & 8908 & 70975 & 289,1 & $\begin{array}{l}43 \text { (long-distance) } \\
696 \text { (suburban) }\end{array}$ \\
\hline October & 10363 & 66570 & 279,9 & $\begin{array}{l}22,1 \text { (long-distance) } \\
133,1 \text { (suburban) }\end{array}$ \\
\hline Privolzhskaya & 4277 & 29716 & 129 & $\begin{array}{l}7,8 \text { (long-distance) } \\
6,2 \text { (suburban) }\end{array}$ \\
\hline Sverdlovskaya & 7153 & 57545 & 320,7 & $\begin{array}{l}12,8 \text { (long-distance) } \\
23 \text { (suburban) }\end{array}$ \\
\hline Northern & 5956 & 43970 & 255,4 & $\begin{array}{l}10,6 \text { (long-distance) } \\
7,5 \text { (suburban) }\end{array}$ \\
\hline North-Caucasian & 6352 & 52060 & 172,5 & $\begin{array}{l}17,5 \text { (long-distance) } \\
24,4 \text { (suburban) }\end{array}$ \\
\hline South-East & 4235 & 36384 & 196,3 & $\begin{array}{l}17,3 \text { (long-distance) } \\
10,1 \text { (suburban) }\end{array}$ \\
\hline South Ural & 4545 & 44024 & 322,5 & $\begin{array}{l}6,4 \text { (long-distance) } \\
6,7 \text { (suburban) }\end{array}$ \\
\hline
\end{tabular}

Table 4. The structure of tasks to reduce the impact of negative factors affecting the frequency of incidents, dangerous and emergency situations.

\begin{tabular}{|l|c|c|c|}
\hline \multirow{2}{*}{ Tasks } & \multicolumn{3}{|c|}{ Impact of negative factors } \\
\cline { 2 - 4 } & Incidents & Dangerous situations & $\begin{array}{c}\text { Emergency } \\
\text { situations }\end{array}$ \\
\hline Technical & + & + & + \\
\hline Technological & + & + & - \\
\hline Economic & + & - & - \\
\hline Logistic & + & + & + \\
\hline Environmental & + & + & - \\
\hline Protection of employees & + & + & + \\
\hline
\end{tabular}

Our analysis [6] shows that the risk magnitude of fatal (lethal) injuries for the company's employees is $510^{-5}$. This is much less than the rate of unacceptable catastrophic risk, which is equal to $10^{-3}$, but also significantly larger than the magnitude of "acceptable risk" and "reasonable sufficiency", which is adopted as $10^{-6}$.

In order to implement current production activity, the structural unit must have production personnel with the necessary professional competencies provided for by the qualification in the field of safety (Table 2), taking into account the observance of obligatory inter-certification terms. A feature of many production processes of railway transport is the impossibility of deterministic planning; one should take into account the stochastic nature of the traffic. Taking into account the significant costs and possible losses (risks), it seems promising to optimize the provision of the necessary conditions: 1) the optimal combination of qualifications; 2) the fulfillment of the obligatory terms for certification shall be implemented as a unit integrated into the IMS "TS".

In JSC "RZD", the process of combining professions and bringing them to a certain level of universality is going on rather quickly. The modern level of development of science and technology, namely, the use of portable mobile devices, global geo-positioning, constant access to an array of all necessary data and information, automation of processes and their robotization, allows the authors to make the assumption that the process of combination will go very intensively at the turn of the innovation development of the 
Company until 2050. In addition, the expediency of dividing directorates and services and the widespread introduction of outsourcing is questionable. And there are several reasons for this. Firstly, the redundancy of personnel of narrow (one can call it a traditional) specialization inevitably leads to incomplete employment per shift, generating unproductive down time. Secondly, it is a constant financial burden on the employer (the Company) due to the payment of wages, personal income tax, payments to Federal Compulsory Medical Insurance Fund and Social Insurance Fund. Besides, all these people need to be taught; they need to upgrade (confirm) the qualifications, undergo preliminary at the admission and periodic medical examinations. They must be provided with personal protective equipment, special clothing and footwear, washing and disinfecting agents, vaccinated against tickborne encephalitis, etc. At the same time, when combining professions, there will be a natural sufficiency and full value of man-loading, it will be possible to maneuver labor resources on a wide operating domain, significantly reduce the personnel costs. Comparative analysis and factors of the expected positive effect from combining professions are presented in Figure 1.

This is also convincingly demonstrated by foreign experience. With approximately the same volume of transport work, on average $100 \mathrm{~km}$ of the operational length of railways in Russia and the United States account for almost 1400 and 150 people engaged in transportation, respectively [8]. This also serves as an additional incentive both for investments in "human capital" and for the development of information technology.

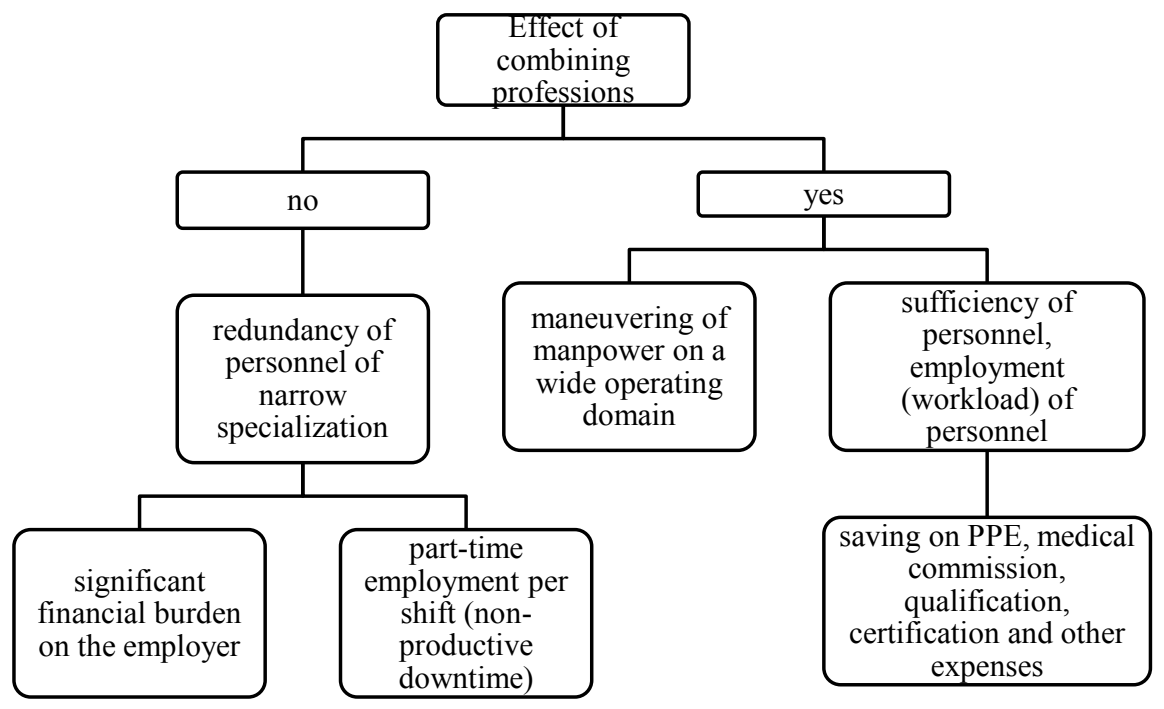

Fig. 1. Expected positive effect of combining professions.

Since qualification is a part of labor capital, it affects the professional suitability of the employee and in this sense has a positive multiplicative character. It is also possible to take into account the indirect positive effects, including the impact on productivity growth, on the efficiency of production in general [7].

Formalization and algorithmization of the competence management unit (taking into account the inevitable combination of professions) within the framework of the IMS "TS" is based on several initial assumptions.

1. The professional potential of each employee must be assessed through a "set of qualifications" defined by the formula (1):

$$
R=R \operatorname{mp} i+R 1 \mathrm{ad} j+R 2 \mathrm{ad} n+\cdots+R N \mathrm{ad} n
$$


where $R \mathrm{mp} i$ - category of the main profession; $R 1 \mathrm{ad} j$ - category of the $1^{\text {st }}$ additional profession; $R 2 \mathrm{ad} n$ - category of the $2^{\text {nd }}$ additional profession; $R N$ ad $n$ - category of $\mathrm{N}^{\text {th }}$ additional profession.

2. Each employee in accordance with his "set of qualifications" must have a "set of certifications". General certification for the current period is determined by the availability of private certifications:

$$
\mathrm{OHS}(i, j)+\mathrm{IS}(i, j)+\cdots+\mathrm{ES}(i, j)+\cdots \mathrm{WM}(i, j)
$$

where OHS $(i, j)$ - certification on "Occupational health and safety" with the expiry of the validity period in ( $i$ - month, $j$ - year), IS $(i, j)$ - certification on "Industrial safety", ES $(i, j)$ - certification on "Electrical safety" and other relevant directions of safety (see Table 2).

3. To manage qualifications and certifications in order to optimize costs, it is necessary to build a mathematical model illustrated by the formulas and graph below. From the perspective of technical and economic efficiency (E), four situations are considered: Emin each employee has one qualification and a minimum set of certifications; Efact - the supposed combination - structure (for the current period); Eopt - the optimal structure; Emax - each employee has almost all qualifications (within the production tasks of the unit) and certifications.

The number of employees of the company, changing in time, is determined by the equation (3):

$$
\sum_{i=1}^{N_{o}} N_{i}+n=N_{t}
$$

where $N_{t}$ - the number of actually employed workers, it is always unstable, but the monthly fluctuation does not exceed $\mp 1 \%, \mathrm{~N}_{0}$ - the value of the previous period; $\mathrm{n}$ - increase in the current period.

Equation (4) shows that we should strive for an optimal structure by the number of employees with certain qualifications and competenciesa ${ }_{i}$ :

$$
\sum_{i=1}^{K} \mathrm{a}_{i} N_{i} \rightarrow o p t
$$

where $\mathrm{a}_{i}=1, \mathrm{~K}=2$ - worst case.

The structure of qualifications and competencies $\mathrm{a}_{i}$ should strive for optimality:

$$
\sum_{i=1}^{K} \mathrm{a}_{i}=\mathrm{a}_{n}-o p t
$$

For planning and ensuring optimal costs, it is necessary to make a forecast for $N_{i}(t)$ and $\mathrm{a}_{i}(t)$.

Estimates of the distribution of the number of employees of JSC "RZD" by the number of qualifications (Figure 2) and changes in the number of employees of the company (Figure 3) were made on the basis of available statistical data and methods [9-13]. The trend of the distribution change in Figure 2 will be determined primarily by the objective necessity of combining professions. The change in the number of workers in time, shown in Figure 3, is determined by factors of optimization of the number: firstly, reduction due to the combination of professions; in the following period, growth due to the growth of the transportation operation domain and the development of the HSL. 


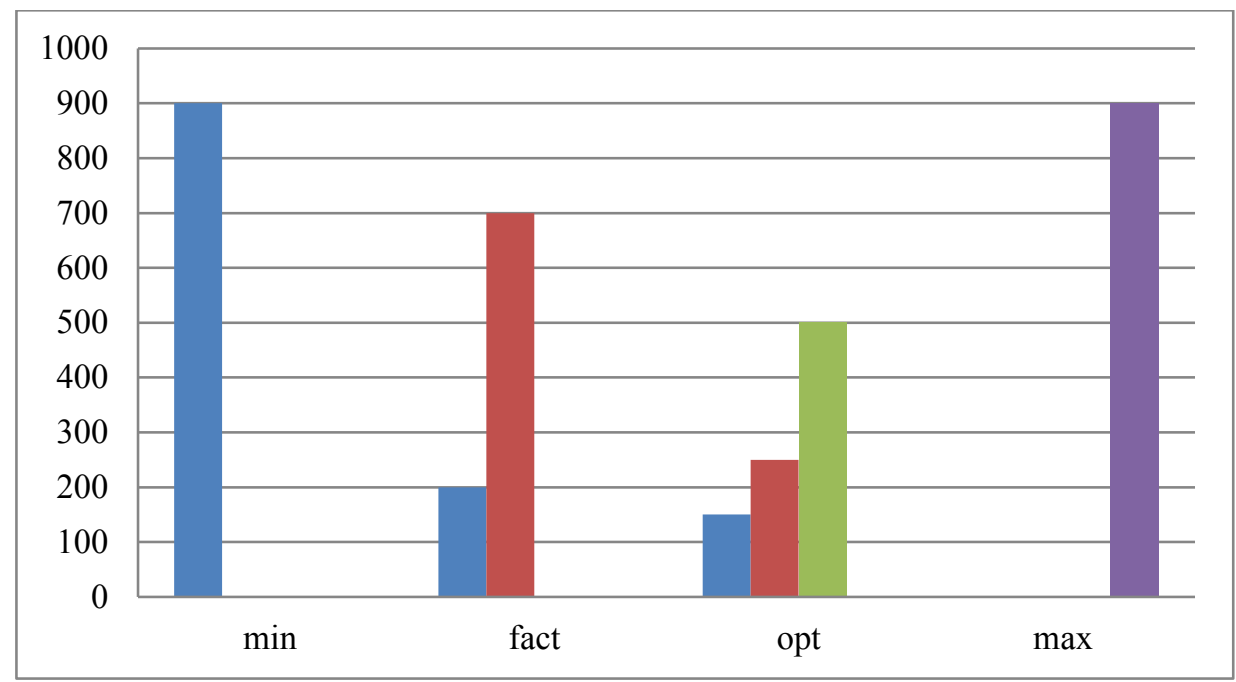

Fig. 2. Distribution of the number of employees by the "number of qualifications" relative to the effectiveness E (thousands of workers).

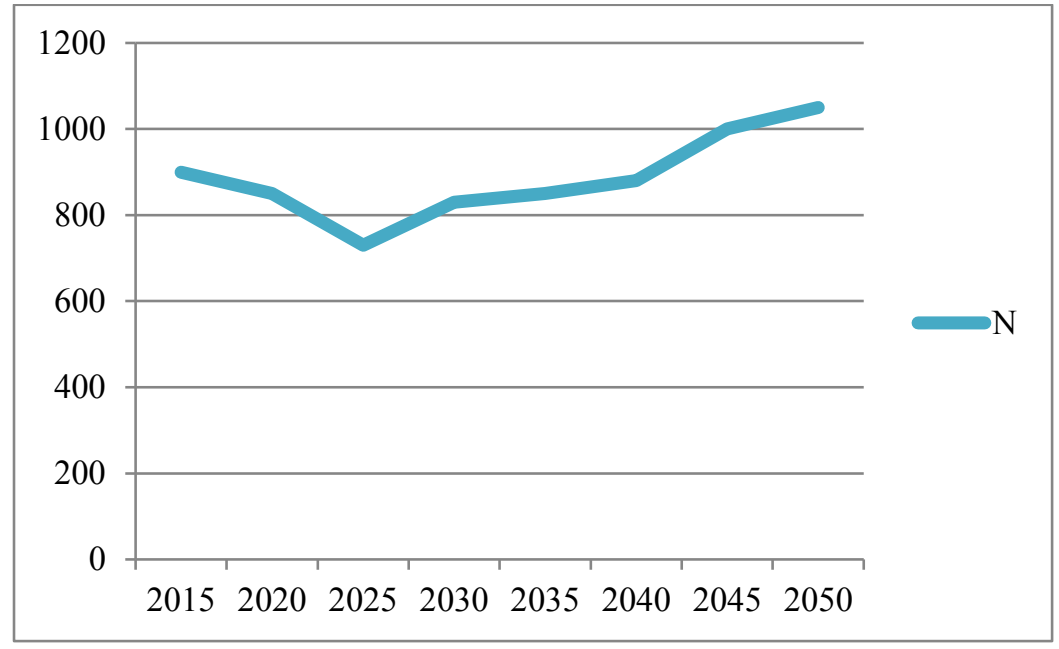

Fig. 3. Forecast of changes in the number of employees.

The integrated safety system for workers and traffic in railway transport should be based, first of all, on the rational use of the labor potential of workers. In the next paper, a draft of regulatory and technical document regulating changes in the current rules and instructions will be presented to familiarize the managers of JSC "RZD" and prepare management decisions. Estimation of the expected efficiency from the implementation on a branch scale is $8-10 \%$, which will allow directing the cost savings for the modernization of technology and the elimination of workplaces with hazardous and harmful working conditions. Within the system, its universal character is proved, i.e. the possibility of application on other modes of transport and in the manufacturing industries.

This stage of the research allows formulating the following main conclusions:

1. Ensuring safety, traffic stability, reducing the frequency of incidents, dangerous and emergency situations remains a priority task for JSC "Russian Railways". Persistent search for new solutions and their implementation are required for its solution. 
2. Scientific understanding and management of the processes for increasing the speed of traffic, expansion of the HSL operating domain, and the impact of these factors on occupational injuries and the number of employees are required. The rate of reduction in occupational injuries to an acceptable level should be increased, including by increasing the expenses for R \& D.

3. Development and implementation of the information and control system "Technospheric safety" as an element of information technology in transport is an objectively urgent task in the light of optimization of labor and financial resources.

\section{References}

1. N.A. Makhutov, M.M. Gadenin, A.M. Sokolov, E.Yu. Titov, Vestnik VNIIZhT 6, 3-12 (2014)

2. O.A. Bogomolov, Internet Journal Naukovedenie 1(6), 11 (2011)

3. The results of implementing the environmental strategy, http://www.rzd.ru/static/public/ru?STRUCTURE_ID=1413\&

4. Analysis of the safety status in JSC "Russian Railways" in 2017

5. Public declaration of the goals and objectives of the Ministry of Emergencies of Russia for 2017, http://www.mchs.gov.ru/dop/opendata/dop/Publichnaja_deklaracija

6. V.I. Medvedev, P.G. Strykov, A.A. Basalaeva, Comprehensive approach to the motivation of safe labor in railway transport, Systematic enabling of decent work conditions: materials of the 1st All-Russian Scientific and Practical Conference, 77 85 (2017)

7. G.N. Gorshkova, FON-nauka 12(39), 9-10 (2014)

8. D.V. Korobeinikov, S.V. Metlushin, Features of emergency situations in railway transport: Study guide (Publishing house "Udmurt University", Izhevsk, 2015)

9. V.M. Ponomarev, Methods and means of improving the safety and stability of the functioning of railway transport in emergency situations: author's abstract (PTC GI MIIT, Moscow, 2011)

10. A.M. Zamyshlyaev, Improvement of traffic safety on the basis of a comprehensive assessment of the state of the railway station infrastructure (Printing house MIIT, Moscow, 2005)

11. N.G. Shabalin, Principles of the organization of control systems for the technical condition of the railway transport infrastructure to ensure the safety of train traffic (Publishing House of SSTU, Novosibirsk, 2004)

12. Yu.I. Druzhinina, Methodological toolkit for estimation of personnel at railway transport enterprises (Editorial and publishing department of the Siberian Academy of Finance and Banking, Novosibirsk, 2011)

13. HSL projects, http://www.rzd.ru/static/public/ru?STRUCTURE_ID=5098 